\title{
1. Redefining success beyond economic growth and wealth generation: the case of Ethiopia
}

\author{
Atsede T. Hailemariam and Brigitte Kroon
}

Entrepreneurship research and policy formulation share a discourse of economic growth and individualism, where female entrepreneurs and their business are seen as underperforming (Marlow and McAdam, 2013). However, such studies neither highlight the complexity of the female entrepreneurship experience in the socio-economic context nor illustrate the influence of specific cultural, legislative, and economic factors on women's entrepreneurial endeavors (Henry et al., 2016). More than half of all women entrepreneurs in Ethiopia often face gender-related challenges in establishing new businesses as well as in operating or expanding existing businesses (Amha and Ademassie, 2004). Their businesses are particularly disadvantaged with regards to access to finance, skills, government support, and the conversion of profit back into investment (Bekele and Worku, 2008; Belwal et al., 2012; Singh and Belwal, 2008).

In particular, challenges that disadvantage women entrepreneurs are found in the culture, religion, and tradition (Bekele and Worku, 2008). Family responsibility, household obligations and lack of support constrain them in confronting these challenges (Belwal et al., 2012). Moreover, in a country like Ethiopia, with no social care system, women play a central role in the extended family. Overall, familial, structural, and cultural constraints have impacts on performance of female-owned businesses. Thus, as Marlow and McAdam (2013) put forward, women-owned businesses demonstrate constrained performance but not underperformance. Hence, a crucial step before concluding that the majority of women entrepreneurs are underperforming is to understand what success in business actually means to the women entrepreneurs themselves within the socio-economic context in which they operate their businesses.

There is some recognition that entrepreneurs' evaluations of success go beyond economic returns (Wach et al., 2016a) and that success in business cannot be equated simply with firm performance or with financial rewards 
(Sarasvathy et al., 2013). Moreover, comparing micro and small enterprises' success only along the female-versus-male-owned nexus may generate an impression of 'false universalism' that ignores the heterogeneity of small firms managed by women entrepreneurs (Marlow and Patton, 2005).

Women entrepreneurs are a heterogeneous group differing in where they live, their level of education, their experience, and their networks. Although reports on women's entrepreneurship in sub-Saharan Africa such as Ethiopia indicate that most women-owned businesses operate in the informal sector of the economy based on a necessity to survive (GEM, 2013), a new class of women who are starting their businesses by their own choice rather than out of necessity in the formal sector of the economy is steadily growing in Ethiopia. Despite the financial, cultural, and other disadvantages they face, these women entrepreneurs create significant numbers of employment opportunities for others (ILO, 2003). What distinguishes these women from those operating necessity-motivated ventures is the element of choice: they choose to be an entrepreneur in order to do what they love most or to achieve independence and to fulfill their values, ambitions, and desires in life (Hailemariam et al., 2017). Hence, financial performance measures alone do not capture their perception of success, as their success criteria are tightly related to their motivation to become an entrepreneur in the first place (Buttner and Moore, 1997).

Overall, the motivation and goals for getting into and staying in business, in combination with socio-cultural attributions like family values, influence how this specific group of women entrepreneurs define business success (Toledo-López et al., 2012). The research presented in this chapter explores how women entrepreneurs in the formal sector of Ethiopia's economy define success in their own terms. By attuning the meaning of entrepreneurship to women's experiences, greater credibility and legitimacy can be afforded to their entrepreneurial activities (Ahl and Marlow, 2012). Moreover, when various aspects of success beyond economic growth are known, identification with entrepreneurship may be easier for women and it may become a more socially desirable career to them. An understanding of the diversity of women entrepreneurs' definitions of success and how this is related to their goals and experience are also vital for government and donors offering support for potential or existing women entrepreneurs.

\section{THE CONTEXT FOR WOMEN ENTREPRENEURS IN ETHIOPIA}

The revised Micro and Small Enterprise (MSE) development strategy and policy initiated by the Ethiopian government in 2011 has mainly focused 
on sustainable job opportunities for the unemployed. It includes women entrepreneurs as one of the target groups. The government also initiated a National Policy on Ethiopian Women in 1993, with the aim of eliminating gender and cultural biases that hinder women from participating equally in the economic development of the country. Moreover, the family code policy revised in 2000 aims to eliminate a husband's ability to deny permission for his wife to work outside the home, and requires both spouses to agree in the administration of family property.

Although there is considerable variation within Ethiopia, the global gender gap report 2015 (World Economic Forum, 2015) ranks Ethiopia at number 124 in the list of 145 countries in terms of the magnitude and scope of gender disparities, which shows for example the unbalanced ratio of male to female school attendance. In particular, the patriarchal gender culture in higher-educational institutions exposes female students to sexual harassment and violence and to prejudice and low expectations from male peers (Molla and Gale, 2015).

Overall, the nature of violence against women in Ethiopia is strongly related to cultural beliefs. Women are expected to show the utmost respect and submission to their husbands and to take on the caring and household responsibilities. This tendency also finds justification in religion and has been maintained for centuries (Biseswar, 2008). However, despite all the challenges, the condition of women is not homogeneous in Ethiopia. Many women are able to overcome the structural barriers they face, to actively participate in economic activities. Hence, the way in which a woman entrepreneur in Ethiopia defines her success depends upon her gendered socialization, her motivation, her background, and her value priorities.

\section{THE DEFINITION OF BUSINESS SUCCESS}

Motivation and goals for getting and staying in business and socio-cultural attributions such as family values influence how women entrepreneurs define business success (Toledo-López et al., 2012). The importance attached to specific business-success factors varies with the heterogeneity of industry sectors (Wach et al., 2016a) and the age of business owners (Warr, 2008). For example, career prospects and high income are especially valued by younger people who have not yet acquired material goods and related status (Warr, 2008). On the other hand, increasing age is associated with a value shift away from extrinsic towards intrinsic and generous motives, helping other people and contributing to society (Kooij et al., 2011; Lang and Carstensen, 2002).

How small business owners define success also varies greatly depending 
on the type of business and on the owner's value priorities, including the reason for starting the business. Personal values are found to be drivers behind business owners' choice of success criteria (Gorgievski et al., 2011). Personal values are desirable goals, varying in importance, that serve as guiding principles in people's lives. People pursue qualitatively different types of goals which will lead to considerably different outcomes (Deci and Ryan, 2000). Self-determination theory (SDT) categorizes goals into intrinsic and extrinsic goals. Intrinsic goals include feelings of community, affiliation, health, and self-development, while extrinsic goals include image, financial success, and appearing physically attractive (Kasser and Ryan, 1993, 1996, 2001). SDT also posits that the social context that exists in the family, cultural values, and economic system affects whether people's life goals or aspirations tend to be more intrinsic or more extrinsic, which in turn affects important life outcomes (Deci and Ryan, 2012).

In summary, because entrepreneurs often pursue goals beyond economic gains (Jennings and Brush, 2013), they have their own perceptions of what success means to them. They can regard themselves as successful, even if (looking from the outside with economic growth and profit measures) their businesses have attained different levels of success (Simpson et al., 2004). Hence, entrepreneurial success is a multi-dimensional construct that is best captured by more than financial and economic indicators (Fisher et al., 2014). Entrepreneurial values contain various indicators of success, such as firm performance, workplace relationships, personal fulfillment, community impact, and personal financial rewards (Wach et al., 2016b). Building on this notion of different dimensions of success, the qualitative research presented in this chapter explores how women entrepreneurs in Ethiopia define success in their own terms.

\section{RESEARCH METHODOLOGY}

Qualitative case studies, narratives or interpretive studies help to shed light on the actions and efforts in entrepreneurship that are unique to women (Brush and Cooper, 2012). Therefore, we used semi-structured interviews with women entrepreneurs who own small firms and applied a qualitative content analysis method to analyze the data (Hsieh and Shannon, 2005).

The study was conducted in Addis Ababa, the capital city of Ethiopia, because the city is populated with people from different ethnic groups and because various kinds of women-run businesses are found there. Eighteen women entrepreneurs who are owners of their current business in the formal sector of the economy were selected, using a mixed approach of purposive and snowball sampling techniques (Patton, 2002). To identify 
the first group of participants, four different women's associations in Addis Ababa were contacted. Respondents were then asked at the end of their interview to recommend other women entrepreneurs. The women entrepreneurs included in this study operate in different business sectors, their ages range from 28 to 55 years, and the ages of their businesses range from six months to 21 years.

\section{Data Collection and Analysis}

Data collection was conducted using semi-structured face-to-face interviews, with questions developed in advance. The interview protocol was piloted to ensure that the interviewees fully understood the questions and there was a logical progression in the sequence of questions and answers (Patton, 1987). The first author of this chapter and another female researcher on women entrepreneurs from the same institution conducted the interviews at the place where the participants run their businesses. The author conducted the interview and the other researcher took detailed notes without actively participating. All participants were assured that under no circumstances would their personal identity or business name be identified. The interviews lasted between 45 minutes and one hour and 15 minutes. Interviews were audio-recorded, transcribed, and then professionally translated from Amharic (the lingua franca of Ethiopia) into English.

Two of the authors of the study then independently content-analyzed each interview transcript. This was done by initially identifying categories by reading and becoming familiar with the data and using the literature review. Then the authors coded the data independently according to the predetermined categories. After the completion of the coding, both authors compared notes and, when coding differences existed, discussed until a consensus was attained. Some categories were revised, removed, and added during this procedure. Data that could not be coded into one of the predetermined categories was coded with new categories. After the coding process the categories were used to construct a set of thematic charts (Ritchie et al., 2013). The analysis was then conducted through a within and cross-case approach, which is the most appropriate technique for exploring relationships among different cases (Eisenhardt and Graebner, 2007). 
Table 1.1 Categories and descriptions

\begin{tabular}{ll}
\hline Category & Description \\
\hline Financial success & - To generate income \\
& - for a better life and education for children \\
& - to sustain the business \\
& - to be financially independent \\
Growth and profit & - To modernize and grow traditional food \\
& - processing \\
& - To maximize profit \\
& - To create more employment opportunities \\
- To grow by expanding the business & - To satisfy customers \\
Stakeholder satisfaction & - To do what I love to do, to be passionate and \\
& - creative \\
& - To be proud by introducing culture and tradition \\
& or by seeing people using products marked as \\
& - Tade in Ethiopia' \\
- To contribute to my country & - To contribute to my religion \\
\hline
\end{tabular}

Note: a. The descriptions are the abbreviated versions of what the participants expressed as definitions of success.

\section{FINDINGS AND DISCUSSION}

The interviews with the women entrepreneurs revealed various descriptions of what success meant to them. The data analysis yielded five categories of success criteria that the participants in this study used to define their success in business: (i) financial success, (ii) profit and growth, (iii) stakeholder satisfaction, (iv) self-fulfillment, and (v) societal contribution. Table 1.1 shows the categories with the corresponding descriptions. In this section direct quotes from participants are presented to illustrate each category of success definition. Participants are identified as '(Type of business - Age - Education).'

\section{Financial Success}

Financial success was referred to as income generated from the business. Although it frequently appeared as an indicator for success, none of the participants used it as the sole indicator of their success. Rather, they 
perceived financial success primarily as a vehicle to advance their families and to fulfill their own psychological needs for autonomy and relatedness (Deci and Ryan, 2008; Ryan and Deci, 2000). For example, one of the participants who said 'It's not about the money for me, it's when people love what I do' mentioned the importance of the financial success as follows:

I want a better life ... [Ehhh] and to educate my kids, to work hand in hand with my husband and to attain success ... You see, I say (to spouse), 'We need to have security, money we can rely on in case of an emergency, so let's set some money aside and save it.' (Traditional cloth and accessories designer - 50 Bachelor's degree)

This quote illustrates that even some women who are motivated to start a business for reasons other than necessity reinvest a big proportion of their earnings from the business in their families. This may be due to the societal expectation that ascribes women to take the role of caring and household responsibility. In most African societies, women are seen to exist not for themselves but for the collective, and are expected to sacrifice their own well-being for that of the community as a whole and the family in particular (Biseswar, 2008).

Similarly, another participant, whose first definition of success was 'doing something that makes people happy also makes me happy,' mentioned the importance of financial success as follows:

I don't measure my success financially; however, the business has to survive at least to support itself. (Yoga and massage - 37 - Master's degree)

For this participant, the survival of the business was important to fulfill her intrinsic need. On the other hand, some women needed the income generated from the business to become autonomous. By becoming finically independent they could fulfill their needs and help others. Within most Ethiopian households, the head alone (almost always a man) administers key decisions on major expenditures. Women who bargain in overt ways and confront their husbands during household decision-making are often threatened with or face marital dissolution (Fafchamps and Quisumbing, 2005). Consequently, one way of maintaining power in a relationship is to retain control over financial resources. In addition, men's violence can restrict and subordinate women's participation in societal institutions. The following quote from one of the participants illustrates that the financial success of her business is important for the financial freedom it provides her to do what she likes.

I don't need to ask my husband for anything. If I wanted to help someone in my society or if I went to a funeral in my community, I can do something for them 
by my own. If I wanted to fuel my car, I don't need to ask my husband. I can do what I please . . . (Traditional cloth designer - 48 - Diploma)

Overall, the above findings support the view that some women still value financial success (Carter et al., 2003), but rather than reinvesting their profits in their business, they are more likely to spend their income on family and household needs, save cash for emergencies, or both (Klapper and Parker, 2011; Watson, 2002). This may be due to their socialization in a society which associates women with female gender roles such as nurturing children, maintaining the household, supporting their husbands, and caring for others. In particular, in a society such as Ethiopia where households are composed of the nuclear family and extended family and where there is no social care system, some women entrepreneurs' early and ongoing socialization experience influences them to accept and internalize caring and communal goals (Eagly and Wood, 1991). Hence, women who mentioned the financial success of the business as a success criterion did so because they acknowledged its importance for sustaining their business as a source of income for the financial freedom it provides for their children's better education, for unexpected household expenses, and for fulfilling intrinsic values in life.

\section{Profit and Growth}

Some participants in the study had clear financial measures in terms of profit and growth targets as primary goals. For example, a participant involved in marketing her company's product in foreign markets had the following to say about profit in her definition of success:

Success for me is to be on top of my game and to compete with other businesses engaged in the same line of work. In order to do this, I strive to come up with a distinct product and a brand name. I even dream of being competitive in the global market while managing to be profitable every year. That's what success means to me. (Footwear company - 31 - Diploma)

A young, educated participant who introduced a new market for processing and packing traditional food mentioned her growth goal as follows:

To me, success is a phase. For example, I used to work from home. After passing through many challenges, I acquired this place. This is success and I will use this as a stepping-stone to the next phase. I will say I am very successful when 
I get to see this business growing to a larger industry. (Food processing and packing - 28 - Master's degree)

Another young and single participant running a souvenir shop socialized in one of Ethiopia's ethnic groups known as 'Gurage,' who are known for their business culture and who are recognized as mobile and skilled traders in urban settings (Worku, 2000), defined her success in terms of maximizing profit. Moreover, participants who were operating more than one business and had experience in another business defined their success in terms of traditional firm performance-measure criteria. For example, one participant who started her business in the clothing retail sector while she was a university student, and who currently operates two different businesses, expressed her definition of success in terms of creating employment for others:

Of course, your first aim is financial freedom. But success doesn't mean just that. If you have something of your own then being able to employ others is also success. Seeing the reality, there are a lot of capable young people and being able to employ one or two people, for me, is quite satisfactory more than anything else. (Consultant and food supermarket - 36 - Master's degree)

In addition to this participant there were serial entrepreneurs in this study who started their business as micro in the informal sector and who later moved to the formal sector operating other small firms, who defined their success in terms of expansion and profitability. For example, a participant who said, 'I would consider myself successful when everything I dreamt and hoped for happens,' and was then asked what are the things she hopes and dreams of, mentioned:

My future dream is to buy land and start a cattle rearing business. On the same land, I also hope to start chicken farming. (Dairy products and taxi service 34 - Elementary school)

Overall, this group of women who defined their success in terms of profit and growth differs from the group where a financial success criterion is embedded in societal expectations about the female gender role. The women in this group are either young, at higher-education level, have previous business experience, operate in a male-dominated sector, or belong to an ethnic background that allowed a different kind of socialization. This aligns with previous research that found business owners' goals may vary depending on individual and business demographic factors (Stewart $\mathrm{Jr}$ et al., 2003) and the heterogeneity in industry sectors (Wach et al., 2016b). For example, because food and textile businesses are gaining importance, 
along with the movement to buy local, entrepreneurs engaged in these sectors are better positioned to grow their businesses (Kelly et al., 2015).

\section{Stakeholder Satisfaction}

Stakeholder satisfaction (customers, employees) was often mentioned as part of the success definitions. For example, one of the participants defined business success in terms of customers' satisfaction as follows:

... didn't like upsetting them (customers). How can you disappoint people and still love what you do? If you did it for the sake of money, maybe then you wouldn't mind disappointing a customer because there will always be another one. (Traditional cloth designer - 48 - Diploma)

Similarly, the following quote illustrates business success in terms of employee satisfaction:

Success for me is about fulfilling my responsibilities. Are the workers happy? . . . Am I happy with the work I'm doing, because money alone can't make you feel happy. (Diagnostic center and retail shops - 34 - Bachelor's degree)

As the above two participants mentioned, stakeholder satisfaction is an intrinsic goal that contributes to self-determination (Deci and Ryan, 2000). The participants also defined business success in terms of achieving other intrinsic goals. In particular, self-fulfillment goals and societal contributions were mentioned and will be elaborated upon in the next sections. These success definitions support the view that success in business cannot simply be equated with firm performance or with financial success (Sarasvathy et al., 2013), and that entrepreneurs pursue goals beyond economic gains (Jennings and Brush, 2013).

\section{Self-fulfillment}

About 30 percent of the participants mentioned that they are motivated to start a business to do what they love to do. Due to the entwined nature of the business and the owner, the participants viewed their satisfaction in personal life as business success. The following quote is from a participant who mentioned yoga as a hobby and who is involved in the yoga and massage business:

Passion; to be passionate about what you are doing and being creative. You know, even doing something meaningful for someone, like when I see people coming and getting relief from their pain and stress and becoming happy, makes me feel I am successful. (Yoga and massage - 37 - Master's degree) 
Another example of self-fulfillment success criteria comes from Diaspora and repatriate women entrepreneurs. Their life experience in foreign countries helped them develop a sense of their Ethiopian identity which in turn enhanced their love for the different cuisines, cultural ornaments, attire, and the other cultural aspects of their country. They expressed their business success as promoting and contributing to the betterment of their country, as the following quote by a repatriate participant who is engaged in running a guesthouse illustrates:

Success for me isn't only when people come to stay at my place but also when they learn about the country and its diverse cultures ... When people leave satisfied and happy, that's a 100 percent success in my eyes. The love for my country is the most important factor. When tourists come to stay at my place, eager to learn about the different cuisines, cultural ornaments, and lifestyles of Ethiopia, it gives me immense satisfaction. I see myself as contributing to my country. (Guesthouse - 51 - Bachelor's degree)

In a similar vein, participants who are engaged in traditional clothes design and art-related businesses stated personal satisfaction as business success, as the following quote illustrates:

It's not about the money for me, it's when people love what I do . . . money is an end result. A lot of people have stopped buying drinking glasses and plates as a gift ... so that's a huge success for me. The biggest success for me is to see people buy traditional Ethiopian-made products and hang them on their walls proudly. (Traditional cloth and accessories designer - 50 - Bachelor's degree)

The above three participants found their business to be important to fulfill their childhood dreams or to turn their hobby into a business or to commit to the culture they missed when they lived abroad. Thus, the success criteria they prioritize evolve around achieving intrinsic goals.

\section{Societal Contribution}

The other success criteria concern achieving intrinsic goals, phrased as contributions to society and religion. Two of the participants mentioned their contribution to poor people in the community by providing them with a free service. One participant who owns a diagnostic center mentioned that she provides CT scan, MRI, ultrasound, ECG, and ambulance services for free to poor people. The second participant who owns an elementary school said that 'when I opened the school there were children who want to learn but cannot afford ... So I thought of how many students I can teach for free in a year.' The following quote illustrates her success criteria in terms of both societal contribution and expansion of her business: 
For me success is the love of work. First, I love what I do and I have a huge respect for it. Second, the fact that I am helping out not less than 10 to 12 people, those that are in need, considering my capacity, that is for me a great satisfaction ... And in the future, what I consider to be a success is when I get to build a building and widen my services while helping the students that I need to help. God helped us to reach this stage and the most important thing is working and serving honestly and God is the one who lies in the heart. (Elementary school - 45 - Bachelor's degree)

Notable in this quote is that the respondent refers to serving God as part of her definition of success. Similarly, some of the participants in this study linked their success criteria to their religious beliefs. For example, a participant expressed her success in terms of helping others and her contribution to religion as follows:

When I dreamed about this at first, my goal wasn't to get up to try and become a millionaire; it wasn't making profit. My thoughts were on how I can help out others through what I did. I am a person of the church. My religion and church teach about helping others. And I had the intention of using the money I make to help to spread the word of God. (Jam producer - 53-Diploma)

This finding supports the view that belief systems in sub-Saharan Africa play a critical role in shaping attitudes toward business and entrepreneurship (Amine and Staub, 2009). The culture, traditions, and values of religious people in Ethiopia are heavily influenced and shaped by their religious beliefs. According to the 2007 population census of Ethiopia the dominant religions, Orthodox Christianity (43.5 percent) and Islam (33.9 percent), each preach about taking care of others and doing good. Consequently, as women in Ethiopia are found to be more religious than men by adhering strictly to their religious obligations (Biseswar, 2008), a profit achieving goal or wealth creation may be of no importance for some religious women entrepreneurs.

In sum, although the interviews revealed that women did mention financial success, profit, and growth, they also attributed success as something to do with other goals, such as stakeholder satisfaction, self-fulfillment, and making a contribution to religion and society. Whereas the language used to express the value of financial success, profitability, and growth success criteria were largely addressing extrinsic goals, the remaining success criteria lay closer to the realization of intrinsic goals (Deci and Ryan, 2000). It is suggested that when people put intrinsic goals first, their performance for the attainment of these goals and the expectation of future goal attainment contribute to their greater health, well-being, and performance (Kasser and Ahuvia, 2002; Vansteenkiste et al., 2006). Thus, those women entrepreneurs in Ethiopia who prioritize intrinsic goals may 
be more persistent in putting greater effort and energy into the continued existence and success of their business on their own terms.

\section{CONCLUSIONS}

This study focused on the question of how women entrepreneurs in Ethiopia define business success in their own terms. Rather than comparing them to men or to women in other countries, the variation in success definitions was sought in a relatively homogeneous group of women entrepreneurs in a single country. Participants defined their success both in terms of financial and non-financial performance measures. The findings indicate that due to their early and ongoing socialization experience as a female in Ethiopia, the majority emphasized family and communal values, stakeholder satisfaction, self-fulfillment, and contributions to society. Even many of those who mentioned their success definitions in terms of financial success emphasized its instrumental value for realizing intrinsic goals. However, some women, who are young, educated, have previous business experience, or who operate more than one business or are engaged in male-dominated sectors defined their success more in terms of financial performance measure criteria as a goal in itself.

Hence, in designing policy and support programs policy-makers should acknowledge that the women entrepreneurs in Ethiopia are not a homogeneous group. Most women use success criteria other than the traditional firm performance criteria that are usually used to assess the success of small firms. When firm performance is conceptualized more in terms of the optimization of personal functioning and well-being, a basic understanding of entrepreneurs' attainment of intrinsic goals should be helpful for policy-makers and donors in facilitating optimal performance and well-being of women entrepreneurs.

Despite the small sample size, the purposive sampling technique proved to be useful in identifying different sub-groups of women entrepreneurs who define their success both in financial and non-financial performancemeasure terms. However, further quantitative analysis including male entrepreneurs needs to be conducted to measure between-sex differences and within-sex differences in the socio-economic context of Ethiopia, to further analyze and understand the various definitions of success. In addition, the relation should be sought with start-up motivations of women entrepreneurs, with the type of sector and background characteristics such as education, age, and gender, to further examine whether gender is salient or stronger than other variables in valuing the success definitions as laid out in this chapter. 


\section{ACKNOWLEDGEMENT}

The authors would like to thank The Netherlands Organization for International Cooperation in Higher Education (Nuffic) for the research grant of NICHE project ETH-020 (Capacity Development of Business and Economics) provided to the first author.

\section{REFERENCES}

Ahl, H. and Marlow, S. (2012). Exploring the dynamics of gender, feminism and entrepreneurship: advancing debate to escape a dead end? Organization, 19(5), $543-562$.

Amha, W. and Ademassie, A. (2004). Rural financial intermediation program and its role in strengthening the rural financial system in Ethiopia. Journal of Microfinance Development Review, 3(2), 230-365.

Amine, L.S. and Staub, K.M. (2009). Women entrepreneurs in sub-Saharan Africa: an institutional theory analysis from a social marketing point of view. Entrepreneurship and Regional Development, 21(2), 183-211.

Bekele, E. and Worku, Z. (2008). Factors that affect the long-term survival of micro, small and medium enterprises in Ethiopia. South African Journal of Economics, 76(3), 548-568.

Belwal, R., Tamiru, M., and Singh, G. (2012). Microfinance and sustained economic improvement: women small-scale entrepreneurs in Ethiopia. Journal of International Development, 24(S1), S84-S99.

Biseswar, I. (2008). Problems of feminist leadership among educated women in Ethiopia taking stock in the third millennium. Journal of Developing Societies, 24(2), 125-158.

Brush, C.G. and Cooper, S.Y. (2012). Female entrepreneurship and economic development: an international perspective. Entrepreneurship and Regional Development, 24(1-2), 1-6.

Buttner, E.H. and Moore, D.P. (1997). Women's organizational exodus to entrepreneurship: self-reported motivations and correlates with success. Journal of Small Business Management, 35(1), 34-46.

Carter, N.M., Gartner, W.B., Shaver, K.G., and Gatewood, E.J. (2003). The career reasons of nascent entrepreneurs. Journal of Business Venturing, 18(1), 13-39.

Deci, E.L. and Ryan, R.M. (2000). The 'what' and 'why' of goal pursuits: human needs and the self-determination of behavior. Psychological Inquiry, 11(4), 227-268.

Deci, E.L. and Ryan, R.M. (2008). Facilitating optimal motivation and psychological well-being across life's domains. Canadian Psychology/Psychologie canadienne, 49(1), 14-23.

Deci, E.L. and Ryan, R.M. (2012). Motivation, personality, and development within embedded social contexts: an overview of self-determination theory. In R.M. Ryan (ed.), The Oxford Handbook of Human Motivation. New York: Oxford University Press, pp. 85-107.

Eagly, A.H. and Wood, W. (1991). Explaining sex differences in social behavior: a meta-analytic perspective. Personality and Social Psychology Bulletin, 17(3), 306-315. 
Eisenhardt, K.M. and Graebner, M.E. (2007). Theory building from cases: opportunities and challenges. Academy of Management Journal, 50(1), 25-32.

Fafchamps, M. and Quisumbing, A. (2005). Assets at marriage in rural Ethiopia. Journal of Development Economics, 77(1), 1-25.

Fisher, R., Maritz, A., and Lobo, A. (2014). Evaluating entrepreneurs' perception of success: development of a measurement scale. International Journal of Entrepreneurial Behavior and Research, 20(5), 478-492.

Forbes (2012). Africa's most successful women: Bethlehem Tilahun. Forbes magazine. Accessed at http://www.forbes.com/sites/mfonobongnsehe/2012/01/05/africasmost-successfulwomen-bethlehem-tilahun-alemu/.

GEM (2013). Global Entrepreneurship Monitor 2012: Women's Report. Accessed 8 April 2016 at www.babson.edu/Academics/centers/blank-center/global-research/ gem/pages/reports.aspx.

Gorgievski, M.J., Ascalon, M.E., and Stephan, U. (2011). Small business owners' success criteria: a values approach to personal differences. Journal of Small Business Management, 49(2), 207-232.

Hailemariam, A.T., Brigitte, K., and Veldhoven, M. v. (2017). Understanding the motivation of women entrepreneurs in Ethiopia. In T.S. Manolova, C.G. Brush, L.F. Edelman, A. Robb and F. Welter (eds), Entrepreneurial Ecosystems and Growth of Women's Entrepreneurship: A Comparative Analysis. Cheltenham, UK and Northampton, MA: Edward Elgar Publishing, pp. 148-171.

Henry, C., Foss, L., and Ahl, H. (2016). Gender and entrepreneurship research: a review of methodological approaches. International Small Business Journal, 34(3), 217-241.

Hsieh, H.-F. and Shannon, S.E. (2005). Three approaches to qualitative content analysis. Qualitative Health Research, 15(9), 1277-1288.

ILO (2003). Ethiopian women entrepreneurs: going for growth. Report, international conference office, Geneva: International Labour Organization.

Jennings, J.E. and Brush, C.G. (2013). Research on women entrepreneurs: challenges to (and from) the broader entrepreneurship literature? Academy of Management Annals, 7(1), 663-715.

Kasser, T. and Ahuvia, A. (2002). Materialistic values and well-being in business students. European Journal of Social Psychology, 32(1), 137-146.

Kasser, T. and Ryan, R.M. (1993). A dark side of the American dream: correlates of financial success as a central life aspiration. Journal of Personality and Social Psychology, 65(2), 410-422.

Kasser, T. and Ryan, R.M. (1996). Further examining the American dream: differential correlates of intrinsic and extrinsic goals. Personality and Social Psychology Bulletin, 22(3), 280-287.

Kasser, T. and Ryan, R.M. (2001). Be careful what you wish for: optimal functioning and the relative attainment of intrinsic and extrinsic goals. In P. Schmuck and K.M. Sheldon (eds), Life Goals and Well-Being: Towards a Positive Psychology of Human Striving. Seattle: Hogrefe and Huber, pp. 116-131.

Kelly, D.J., Brush, C., Greene, P., Herrington, M., Ali, A., and Kew, P. (2015). GEM Special Report: Women's Entrepreneurship. Wellesley, MA: Babson College.

Klapper, L.F. and Parker, S.C. (2011). Gender and the business environment for new firm creation. The World Bank Research Observer, 26(2), 237-257.

Kooij, D.T., De Lange, A.H., Jansen, P.G., Kanfer, R., and Dikkers, J.S. (2011). Age and work-related motives: results of a meta-analysis. Journal of Organizational Behavior, 32(2), 197-225. 
Lang, F.R. and Carstensen, L.L. (2002). Time counts: future time perspective, goals, and social relationships. Psychology and Aging, 17(1), 125-139.

Marlow, S. and McAdam, M. (2013). Gender and entrepreneurship: advancing debate and challenging myths; exploring the mystery of the under-performing female entrepreneur. International Journal of Entrepreneurial Behavior and Research, 19(1), 114-124.

Marlow, S. and Patton, D. (2005). All credit to men? Entrepreneurship, finance, and gender. Entrepreneurship Theory and Practice, 29(6), 717-735.

Molla, T. and Gale, T. (2015). Inequality in Ethiopian higher education: reframing the problem as capability deprivation. Discourse: Studies in the Cultural Politics of Education, 36(3), 383-397.

Patton, M.Q. (1987). How to Use Qualitative Methods in Evaluation, London and New Delhi: Sage.

Patton, M.Q. (2002). Qualitative interviewing. Qualitative Research and Evaluation Methods, 3, 344-347.

Ritchie, J., Lewis, J., Nicholls, C.M., and Ormston, R. (2013). Qualitative Research Practice: A Guide for Social Science Students and Researchers, Thousand Oaks, CA: Sage.

Ryan, R.M. and Deci, E.L. (2000). Self-determination theory and the facilitation of intrinsic motivation, social development, and well-being. American Psychologist, 55(1), 68-78.

Sarasvathy, S.D., Menon, A.R. and Kuechle, G. (2013). Failing firms and successful entrepreneurs: serial entrepreneurship as a temporal portfolio. Small Business Economics, 40(2), 417-434.

Simpson, M., Tuck, N., and Bellamy, S. (2004). Small business success factors: the role of education and training. Education + Training, 46(8/9), 481-491.

Singh, G. and Belwal, R. (2008). Entrepreneurship and SMEs in Ethiopia: evaluating the role, prospects and problems faced by women in this emergent sector. Gender in Management: An International Journal, 23(2), 120-136.

Stewart Jr, W.H., Carland, J.C., Carland, J.W., Watson, W.E., and Sweo, R. (2003). Entrepreneurial dispositions and goal orientations: a comparative exploration of United States and Russian entrepreneurs. Journal of Small Business Management, 41(1), 27-46.

Toledo-López, A., Díaz-Pichardo, R., Jiménez-Castañeda, J.C., and SánchezMedina, P.S. (2012). Defining success in subsistence businesses. Journal of Business Research, 65(12), 1658-1664.

Vansteenkiste, M., Duriez, B., Simons, J., and Soenens, B. (2006). Materialistic values and well-being among business students: further evidence of their detrimental effect. Journal of Applied Social Psychology, 36(12), 2892-2908.

Wach, D., Stephan, U., and Gorgievski, M. (2016a). More than money: developing an integrative multi-factorial measure of entrepreneurial success. International Small Business Journal, 34(8), 1098-1121.

Wach, D., Stephan, U., and Gorgievski, M. (2016b). More than money: developing an integrative multi-factorial measure of entrepreneurial success. International Small Business Journal, 34(8), 1098-1121.

Warr, P. (2008). Work values: some demographic and cultural correlates. Journal of Occupational and Organizational Psychology, 81(4), 751-775.

Watson, J. (2002). Comparing the performance of male- and female-controlled businesses: relating outputs to inputs. Entrepreneurship: Theory and Practice, 26(3), 91-101. 
Worku, N. (2000). Fanonet: ethnohistorical notes on the Gurage Urban Migration in Ethiopia. Ufahamu: A Journal of African Studies, 28(2-3), 43-73.

World Economic Forum (2015). Global gender gap report 2015. Accessed 2 January 2016 at http://reports.weforum.org/global-gender-gap-report-2015/rankings/. 